\title{
ANNELIES LANNOY
}

St Paul in the early $20^{\text {th }}$ century history of religions.

"The mystic of Tarsus" and the pagan mystery cults. After the correspondence of Franz Cumont and Alfred Loisy ${ }^{1}$

Alfred Loisy (1857-1940), the excommunicated French Modernist priest and historian of religions, and Franz Cumont (1868-1947), the Belgian historian of religions and expert in pagan mystery cults, conducted a lively correspondence in which they intensively exchanged ideas. One of their favorite subjects for discussion was the dependence of St Paul on the pagan mysteries. Loisy dealt with this early $20^{\text {th }}$ century moot point for protestant, catholic and non-religious scholars in his publications, while Cumont always remained silent. This study of their unpublished letters sheds new light on the strategies lying behind their publications. It reveals what they chose not to say, and what they meant by what they did say.

"I hope that the calm of the countryside will have brought you rest and strength and that you will soon give us the study about St Paul and the mysteries, which we have been impatiently awaiting." ${ }^{2}$ In his letter of July 11, 1912, the Belgian historian of religions Franz Cumont (18681947) expressed a wish he would not stop repeating until 1914, the year in which Alfred Loisy's (1857-1940) articles on Paul were finally published. Cumont had started writing to Loisy, a pivotal figure in the modernist crisis in the Catholic Church and a French expert in Early Christianity and biblical exegesis, shortly after Loisy's excommunication in 1908 , and the scholars soon became friends. Their correspondence only ended in 1940, when Loisy died. ${ }^{3}$ Between 1911 and 1914, Loisy was working on a series of articles about the relation between the pagan mystery cults and Christianity. These studies formed part of his research and teaching program on sacrifice at the Collège de France (Paris), where he had been appointed to the chair of History of Religions in $1909 .{ }^{4}$ As

\footnotetext{
${ }^{1}$ I wish to thank the Research Foundation - Flanders for financing the project "Christianity, the Oriental Religions and the Mystery Cults in the thought of Franz Cumont, and his work within the context of Liberal Theology and Modernism (Alfred Loisy)" (project G. 0126.08), as part of which this research was conducted. I'm sincerely grateful to my supervisor Prof. Danny Praet for his help and revision of this text. I also wish to thank Prof. Corinne Bonnet and Prof. C. J. T. Talar for their valuable comments.

${ }^{2}$ Cumont to Loisy, 11 July 1912, f ${ }^{\circ} 120$ : “J'espère que le calme des champs vous aura rendu repos et vigueur et que vous nous donnerez bientôt l'étude sur St Paul et les mystères, impatiemment attendue." The English translations of the letters are my own. The LoisyCumont correspondence is kept at the Bibliothèque nationale de France: Cumont to Loisy: BnF, ms. NAF 15651, ff. 64-442; Loisy to Cumont: BnF, ms. NAF 15644, ff. 55-329. Nine letters of Loisy are kept at the Cumont-archives in the Academia Belgica in Rome. - This correspondence is to be published by Corinne Bonnet, Danny Praet, Sarah Rey and myself.

${ }^{3}$ Aline Rousselle initiated the editorial work and published the following introductory article "Cumont, Loisy et la Revue d'histoire et littérature religieuse," Mélanges de l'École française de Rome. Italie et Méditerranée 111/2 (1999), 577-598.

${ }^{4}$ Alfred Loisy, Leçon d'ouverture du cours d'histoire des religions au Collège de France, Paris 1909, 38-43.
} 
Cumont knew from his earlier contacts with Loisy, Paul was to become the key figure in Loisy's theory about the "Christian Mystery." The passage cited above shows that Cumont, who was one of the leading experts in the pagan mystery cults and oriental religions ${ }^{5}$, took great interest in the matter.

Cumont and Loisy studied the pagan mysteries at a moment when scholars heavily debated about their relationship to Early Christianity. ${ }^{6}$ Within these discussions, Pauline thought used to be a central subject for debate. ${ }^{7}$ Cumont frequently compared Christianity and the "religions orientales" - a term he coined -, but he was careful in expressing an opinion about the origin of their similarities. ${ }^{8}$ Contrary to Loisy, who started to participate in the debates once he had left the Catholic Church, Cumont decided to keep at a distance, maintaining that the main focus of his work was "pagan." Except for a limited number of passages, with one of which we will deal further on, one will look in vain for statements in his published work about Paul and the pagan mystery cults.

The historical complexity of the subject and the fact that Cumont did not consider himself a specialist, can certainly explain his reserves, but the polemical nature of the debates about the historical contextualization and comparability of Christianity, in which scholars of different religious and methodological backgrounds participated, is another important factor to be taken into consideration. In the Catholic Church, these developments were restrained by the anti-modernist measures taken against critical scholars as Loisy. And, though often fueled by the comparative studies of the members of the German Protestant religionsgeschichtliche Schule of the Göttingen University, the debates also caused controversy in Protestant milieus, where there were scholars - Adolf von Harnack and Carl Clemen included - who adopted a more reluctant attitude towards the comparative tendencies in the study

${ }^{5}$ By 1911, Cumont had already published some of his most influential works: e.g. Textes et Monuments figurés relatifs aux Mystères de Mithra (Bruxelles 1894-1899) or Les Religions Orientales dans le Paganisme Romain (Paris 1906), first German translation in 1910 (Teubner)

${ }^{6}$ For a concise overview of these early $20^{\text {th }}$ century debates: Volkhard Krech, Wissenschaft und Religion, Tübingen 2002, 261-265.

${ }^{7}$ As e.g. Jonathan Z. Smith illustrated in: Drudgery Divine. On the Comparison of Early Christianities and the Religions of Late Antiquity, Chicago 1990, 64-70, 89-115. Smith discussed Loisy's English article "The Christian Mystery" (cf. infra) only very briefly and left the far more extensive French articles of the "Les Mystères Païens et le Mystère Chrétien" series out of consideration.

${ }^{8}$ E.g. Franz Cumont, Die Mysterien des Mithra. Ein Beitrag zur Religionsgeschichte der römischen Kaiserzeit, Leipzig 1903 (autorisierte Deutsche Ausgabe von Georg Gehrich), 144-149 and Franz Cumont, Les Religions Orientales dans le Paganisme Romain, Corinne Bonnet, Françoise Van Haeperen, eds., Bibliotheca Cumontiana, scripta maiora vol. I, Torino 2006 ( $5^{\text {th }}$ and most recent edition), 7-14 (edition used in this paper).

${ }^{9}$ A statement formulated in the preface of Les Religions Orientales, 6 and often repeated in the correspondence (e.g. Cumont to Loisy, February $13^{\text {th }} 1926, \mathrm{f}^{\circ} 357$ ). 
of Early Christianity. ${ }^{10}$ Moreover, these discussions often revealed disagreement among catholic, protestant and non-religious scholars.

The correspondence gave Loisy and Cumont the opportunity to share their opinions in a confidential atmosphere. Starting from 1911, Paul and his relation to the pagan mystery cults frequently came to the foreground of the epistolary reflections. Mostly, these discussions were triggered by Loisy's articles on "Les Mystères Païens et le Mystère Chrétien". ${ }^{11}$ The scholars' letters about Paul touched upon a variety of subjects: from the pagan influence on Pauline sexual ethics to his theory of salvation. In this paper, we decided to focus on the following questions: how did Loisy and Cumont assess Paul's role in the development of Early Christianity and his possible dependence on the mystery cults?

After a brief outline of their published work on the subject, it will become clear that they both agreed that Paul played a crucial role in the process of Christianization and that he was profoundly influenced by pagan religion. In fact, they only seemed to disagree on two points: the degree of consciousness with which Paul had borrowed from the mysteries and his role within the formation of Christian ritual. As we will see, they discussed these particular points of difference in their correspondence.

\section{Paul and the pagan mystery cults in "The Christian Mystery"}

It was Cumont who first brought up the subject of Paul's relation to the mystery cults in the correspondence. On December 7, 1911 he wrote to Loisy from the United States, where he was giving his lectures on "Astrology and Religion among the Greeks and the Romans"12 at several universities:

"You don't need to write me so that I could get in contact with you, even at the opposite side of the Ocean. I have just read your excellent article on 'The Christian mystery' in the latest issue of the 'Hibbert Journal'. You clearly formulated what seems to me to be the truth itself (...). I wish you'd soon publish your very clear exposition about Paul's essential role in another way than in translation." 13

${ }^{10}$ On this conflict between "liberal protestants" as Harnack, and the new generation of "pro-comparative" scholars, as Reitzenstein: S. L. Marchand, "From Liberalism to Neoromanticism: Albrecht Dieterich, Richard Reitzenstein, and the Religious Turn in Finde-Siècle German Classical Studies", in Bulletin of the Institute of Classical Studies (Out of Arcadia) 2003, 46(S79), 129-160. For an extensive overview of $19^{\text {th }}$ and early $20^{\text {th }}$ century German scholarship on Paul: A. Schweitzer, Geschichte der Paulinischen Forschung von der Reformation bis auf die Gegenwart, Tübingen 1911.

${ }^{11}$ In 1919 the articles were published as a book: Les Mystères Païens et le Mystère Chrétien, Paris 1919 (henceforth: MPMC).

${ }^{12}$ Franz Cumont, Astrology and Religion among the Greeks and the Romans, American lectures on the history of religions, New York 1912.

${ }^{13}$ Cumont to Loisy, 7 December 1911, f ${ }^{\circ} 115$ : "Il n'est pas nécessaire que vous m'écriviez pour que j'entre en communication avec vous, même au delà de l'Océan. Je viens de lire votre excellent article sur 'le mystère chrétien' dans le dernier numéro du 
Earlier in 1911, Loisy had published the English article "The Christian Mystery," in which he had exposed his views on the influences of the pagan mysteries on Christianity for the first time. ${ }^{14}$ Before discussing Cumont's reception of this article, we need to take a closer look at its content. "The Christian Mystery" contained much of the theory Loisy would later develop in the MPMC series (published between 1913-1914). In Loisy's view, Jesus was a Jewish preacher whose gospel primarily concerned the approaching Kingdom of God and ought to be situated in Judaism of that time. ${ }^{15}$ After Jesus' death, a new religion issued from this gospel and progressively detached itself from Judaic tradition, so as to become a universal religion. According to Loisy, this transformation took place under the influence of the pagan mysteries which were then flourishing all over the ancient world. In fact, Christianity itself became a mystery "conceived in its general lines on the same model." 16

Loisy used the writings of Paul to substantiate his thesis. Throughout the course of his article, he emphasized that Paul had played a very important part in the process of transformation. ${ }^{17}$ Yet, at some points, Loisy reduced his individual importance: "It would not be possible to attribute such an evolution, either entirely or in principal part, to the action of a powerful personality, who, in full consciousness of his aim, and with deliberate intention, might have directed the course of faith in this sense." ${ }^{18}$ Loisy emphasized that Paul was part of a general development: "The Apostle of the Gentiles in some manner personifies a movement by which he is carried along while directing it." 19 As Loisy would later expose in the first article of $M P M C$, he thought that all religions were subject to the same historical patterns and systematically evolved from primitive cults to national religions, and finally to universal religions of salvation. ${ }^{20}$ In his study Alfred Loisy als Historiker des Urchristentums, Peter Klein has conclusively shown that Loisy's restriction of Paul's role was linked to the supra-individualistic perspective in which he tended to place Paul's individual psychology. ${ }^{21}$

According to Loisy, the transformation of Jesus' Gospel took place on both the level of religious doctrine and practice. Loisy first examined the influence of the pagan mysteries on the Christian doctrines,

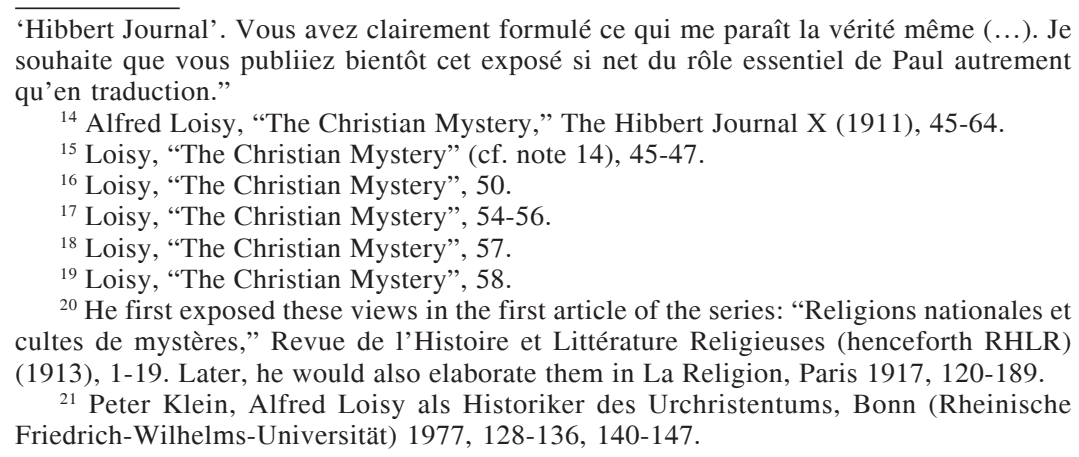


and on Christology more specifically. ${ }^{22} \mathrm{He}$ explained that Pauline theology had transformed Jesus of Nazareth into a universal god of salvation and had provided this deity with his own myth of death and rebirth, under influence of the dying and resurrecting pagan mystery gods. This myth, Loisy wrote, clearly shines trough in Paul's letter to the Romans. The heavenly Christ descended to earth, redeemed mankind through his death and resurrection:

"He was a savior-god, after the manner of an Osiris, an Attis, a Mithra. Like them, he belonged by his origin to the celestial world; like them, he had made his appearance on the earth; like them, he had accomplished a work of universal redemption, efficacious and typical: like Adonis, Osiris and Attis he had died a violent death, and like them he had returned to life; like them, he had prefigured in his lot that of the human beings who should take part in his worship." 23

In his Hibbert-article, Loisy gave only one explanation for the belief in Christ's resurrection: as a myth which had arisen from the influence of the pagan mysteries. From the death of the historical Jesus, he immediately turned to the mythical dying and resurrecting god of Paul. This explanation, strangely enough, contrasted with the psychological reasons Loisy had given for the development of the idea of the resurrection of Jesus in his earlier work. For instance in the volume Jésus et la tradition évangélique (1910), he had attributed the belief in the resurrected Christ to the disciples' incapacity to believe that their leader had actually died. ${ }^{24}$ On this specific point, ,The Christian Mystery” also differs greatly from the thesis Loisy would expose, three years later, in his MPMC. Here, he returned to the psychological explanation and explained that the idea of Jesus' resurrection had initially arisen from the psychological fact that the first disciples could not and would not believe Jesus had died. ${ }^{25}$ Only in a second phase, Loisy now claimed, Christ's resurrection was mythologized along the lines of the pagan myths of death and rebirth. ${ }^{26}$

The larger part of "The Christian Mystery" was dedicated to Christian ritual. ${ }^{27}$ Loisy explained that baptism was initially a rite of purification, and the Lord's Supper a non-ritual communal meal Jesus used to have with his followers. At the time when Paul wrote his first epistle to the Corinthians, they had become rites of initiation through which the worshipper could enter into a mystic communion with Christ and obtain salvation. ${ }^{28}$ Loisy considered Paul to be a key figure in the formation of these sacramental rites. ${ }^{29}$ After Jesus' death, the Lord's Sup-

\footnotetext{
${ }^{22}$ Loisy, "The Christian Mystery" (cf. note 14), 50-52.

${ }^{23}$ Loisy, "The Christian Mystery", 51.

${ }^{24}$ Alfred Loisy, Jésus et la tradition évangélique, Paris 2001, 394-395.

${ }^{25}$ Alfred Loisy, "L’Évangile de Jésus et le Christ ressuscité," RHLR (1914), 73-74.

${ }^{26}$ Alfred Loisy, "L'Évangile de Paul," RHLR (1914), 138-139.

${ }^{27}$ Loisy, "The Christian Mystery" (cf. note 14), 52-58.

${ }^{28}$ Loisy, "The Christian Mystery", 52.

${ }^{29}$ Loisy, "The Christian Mystery", 54.
} 
per got a commemorative meaning, expressing the hope for his proximate return. Loisy argued that Paul had reinterpreted these commemorative meals, under the influence of the pagan mysteries. Paul's 1 Corinthians shows that the worshippers "do not only commemorate this; we may say they go through it over again (la réitèrent) for themselves, as the votaries of Osiris or of Attis renewed for themselves the death of their god." ${ }^{30}$ According to Loisy, the myth that Jesus had instituted the Eucharist was invented by Paul himself: "this narrative is personal to him [Paul], and borrows nothing from the tradition of the Galilean Apostles."31 As for baptism, Loisy explained that in Paul's interpretation this ritual represented Christ's death and resurrection, just like the pagan mystery rites acted out the Passion of their gods. By executing this ritual the worshipper linked his fate to that of the god and could be reborn, too. ${ }^{32}$

Before we examine the content of Loisy's article any further, we need to underline the importance of ritual in his theory about the Christian mystery. This will be crucial to understand the epistolary discussion we will deal with in the second half of this paper. Between 1909 and 1913, Loisy was in the middle of developing his theoretical views on religion. From his inaugural speech at the Collège de France, and studies like "The Christian Mystery," it soon became clear that he started from a ritualistic interpretation of religion. ${ }^{33}$ In the first article of his $M P M C$ series, Loisy made his views explicit and positioned himself in the tradition of the so-called Myth and Ritual School. ${ }^{34} \mathrm{He}$ explained that ritual practice constituted the very centre of religion and preceded myth, which was a rationalization of ritual. In Loisy's view, myth and theology always developed in connection to ritual. In $M P M C$, he applied this scheme to the pagan mystery cults - the myth of a dying and resurrecting god being the rationalization of fertility rites - and to the Christian mystery, where Pauline theology reinterpreted original Jewish practices along the lines of the pagan myth of death and rebirth.

Loisy concluded "The Christian Mystery" by reflecting on the way in which Paul had come into contact with the pagan mystery cults and on the extent to which his thought was indebted to them. He formulated these reflections in reaction to Richard Reitzenstein's influential book, Die hellenistischen Mysterienreligionen nach ihren Grundgedanken und Wirkungen (1910). ${ }^{35}$ According to Reitzenstein, Paul was familiar with

${ }^{30}$ Loisy, "The Christian Mystery" (cf. note 14), 54. The French words between brackets were added by the translator of Loisy's original text.

${ }^{31}$ Loisy, "The Christian Mystery", 54

${ }^{32}$ Loisy, "The Christian Mystery", 53.

${ }^{33}$ Loisy, Leçon d'ouverture (cf. note 4), 30-31: "Mythologie et théologie sont plutôt un produit de la religion que la religion même. On doit examiner d'abord les pratiques religieuses."

${ }^{34}$ Loisy, "Religions nationales et cultes de mystères" (cf. note 20), 14-15. ${ }^{35}$ First English translation by John E. Steely: Hellenistic Mystery-Religions. Their Basic Ideas and Significance, Pittsburgh 1978. 
the pagan mystery literature and drew upon these sacred books for his theology. At that time, many scholars, Loisy and Cumont included, believed that pagan mystery cults had produced secret writings. By stating that Paul himself had consciously made use of the contents of the pagan mystery cults to gain converts, Reitzenstein's theory differed from earlier studies of the religionsgeschichtliche Schule, with which he was commonly associated. E.g. Hermann Gunkel had also been in favor of the theory about a syncretic Christianity ${ }^{36}$, but had situated the actual moment, on which the pagan-oriental influences had taken place, in pre-Christian Judaism, and thus "secured" the Urchristentum to which Protestantism appealed as its religious source. ${ }^{37}$

As a catholic priest, Loisy had already opposed the protestant conviction of a "pure" $1^{\text {st }}$ century Christianity - and the idea it entailed, i.e. Catholicism being a later pagan aberration of this Urchristentum - in his influential essay, The Gospel and the Church (1902). ${ }^{38}$ Having left the Church, Loisy was now free to fully embrace comparative research, and he took over Reitzenstein's conclusions about the direct influence of the mystery cults on Paul. Still, he did not accept the German scholar's assertions about Paul's conscious borrowing, but stated that Paul knew the content of the pagan mysteries only as a result of the contacts he had had with pagan worshippers in Tarsus, "a country where the mysteries of Mithras had been planted before they spread themselves in the Western world." ${ }^{39}$ Paul was heavily influenced by the mysteries, Loisy explained, but he never borrowed a pagan conception without adapting it to the monotheistic Judaic tradition in which Jesus' gospel was anchored. ${ }^{40}$ As for the intentionality of Paul's use of the pagan mystery conceptions, Loisy emphasized that the Pauline transformation of Christianity was not a calculated PR-spin to win pagan converts:

"The translation of the Gospel into a mystery was not thought out (n'ait pas été réfléchie), nor expressly intended even by those who, like Paul, took the most considerable part in effecting the change. The missionary to the Gentiles never calculated that he would make more proselytes by assigning to Christ a place in the scheme of salvation analogous to that of Mithra, Attis, and Osiris, by interpreting baptism as a sacrament of regeneration, and the eucharist [sic] as mystic communion with a crucified and resuscitated Christ." ${ }^{41}$

${ }^{36}$ Hans Gerhard Kippenberg, "In Praise of Syncretism: The Beginnings of Christianity Conceived in the Light of a Diagnosis of Modern Culture", in: Anita Maria Leopold/Jeppe Sinding Jensen (eds.), Syncretism in Religion. A Reader, London 2004, 29-38.

${ }^{37}$ Hermann Gunkel, Zum religionsgeschichtlichen Verständnis des Neuen Testaments, Göttingen 1903

${ }^{38}$ Alfred Loisy, L'Évangile et l'Église, Paris 2001 (edition Mordillat-Prieur), e.g. 100, 153. Loisy's essay was a reaction against Adolf von Harnack, Das Wesen des Christentums, Leipzig 1900.

${ }^{39}$ Loisy, "The Christian Mystery" (cf. note 14), 59.

${ }^{40}$ Loisy, "The Christian Mystery", 45.

${ }^{41}$ Loisy, "The Christian Mystery", 61. 


\section{"The powerful mystic" in Cumont's article for Kultur der Gegenwart}

In the above-cited letter of December 7, 1911, Cumont reacted positively to Loisy's theories and urged him to publish them in French. ${ }^{42}$ Quite exceptionally, his favorable judgment did not remain confined to the correspondence. In 1913, he published a German article, "Die orientalischen Religionen in ihrem Einfluss auf die europäische Kultur des Altertums," in the German encyclopedia Kultur der Gegenwart. ${ }^{43}$ This encyclopedia was founded in 1903 by the German philosopher Paul Hinneberg. It primarily aimed at demonstrating Germany's leading position within the scholarship of that time and it was supported by Emperor Wilhelm II. ${ }^{44}$ For what follows, it is important that the encyclopedia clearly positioned itself in a Protestant tradition. ${ }^{45}$ From the letters Hinneberg wrote to Cumont, we learn that the Belgian scholar ${ }^{46}$ had been asked to write a summarizing article about the influence of the oriental religions on Christianity, with the suggested title "Der Einfluss der orientalischen auf die christliche Religion." ${ }^{47}$ Yet, clearly, Cumont refrained from this suggestive title and went for a more general one.

Interestingly, he dedicated a short paragraph of his article to the role of Paul. He phrased his opinions carefully, but it is clear that they were in line with those of Loisy:

"Er scheint auf das Leben und Leiden Christi, des Weltheilandes, nicht nur die Ausdrücke, sondern sogar die Vorstellungen dieser sakramentalen Kulte übertragen zu haben. Nur handelt es sich jedenfalls nicht um mechanische Übernahme oder sklavische Nachahmung. Der gewaltige Mystiker, in der Atmosphäre der orientalischen Religionen lebend, eignet sich vielmehr ihren

${ }^{42}$ Cumont easily read English. He insisted on a French publication because he had his doubts about the quality of the English translation which The Hibbert Journal had published of Loisy's original French text: Cumont to Loisy, 7 December 1911, f ${ }^{\circ} 115$.

${ }^{43}$ In Paul Hinneberg, ed., Die Kultur der Gegenwart, Teil I, Abt. 3: Die Religionen des Orients und die altergermanische Religion, Leipzig 1913, 243-257.

${ }^{44}$ Michael Stöltzner, "Eine Enzyklopädie für das Kaiserreich," Berichte zur Wissenschaftsgeschichte 31 (2008), 11-28.

${ }^{45}$ Wilhelm Lexis, "Das Wesen der Kultur", in Paul Hinneberg, ed.,

Die allgemeinen Grundlagen der Kultur der Gegenwart, in Die Kultur der Gegenwart, Teil 1, Abt. 1 (Leipzig: Teubner, 1906), 48: "Dem Protestantismus aber bleibt die schwere Aufgabe vorbehalten, die Sache in der im Syllabus [of Errors condemned by Pius IX, 1864] verworfenen modernen Bildung, der geistigen und sittlichen Freiheit und der wissenschaftlichen Objektivität zu vertreten und zugleich das Wesen des historischen Christentums und den christlichen Charakter unserer Kultur aufrecht zu erhalten, also seinen Platz zu behaupten zwischen dem katholischen Dogmatismus und dem wissenschaftlichen Naturalismus."

${ }^{46}$ Cumont's research was well known in Germany. Both his Mysteries of Mithras (in 1903, cf. note 8) and Oriental Religions (in 1910) had been translated in German.

${ }^{47}$ Paul Hinneberg to Cumont, 12 March 1912, Academia Belgica: cote 5226. The passive correspondence of Cumont is kept at the Academia Belgica and is consultable online, through the database of Corinne Bonnet: http://www.academiabelgica.it/acadbel/ askFCnew.php. 
Gehalt an, wandelt ihn um, verchristlicht ihn und predigt ihn kraft göttlicher Inspiration." 48

In accordance with his friend's account, Cumont explained that Paul seemed to have been the one who had transformed Christology by projecting pagan conceptions onto Christ. And, just as Loisy stressed that Paul had adapted the pagan ideas to Judaic tradition, Cumont emphasized that Paul had not adopted the content of the pagan mysteries mechanically. Yet, in spite of these similarities, Cumont's paragraph, however short it may be, also seemed to imply two differences with Loisy's theory. The first difference consists in the fact that Cumont (as Reitzenstein) seemed to think that Paul had adopted the pagan ideas more or less consciously. The second dissimilarity is that Cumont didn't say anything about Paul's involvement in the creation of Christian rituals of initiation, which was an essential part of Loisy's theory. It was precisely these two points of difference Loisy and Cumont discussed in their correspondence. But, before we turn to their discussions, we need to deal with a symptomatic anecdote about the context in which Cumont's article was written.

The correspondence shows us that Cumont sent his article to Loisy shortly after its publication. On July 13, 1913, Loisy wrote a short letter to Cumont with the following teasing remark:

"My greatest thanks and congratulations for the beautiful issue which you have sent me. All this is very wise and of a clarity which has to be lacking to many of your collaborators. However, there is, p. 256, a kraft göttlicher Inspiration which worries me a bit. I'm afraid that you have not understood it in the same sense as the editor and many of your serious German and Protestant readers." 49

In Cumont's article, the words at which Loisy took umbrage are difficult to interpret: "Der gewaltige Mystiker (...) eignet sich vielmehr ihren Gehalt an, wandelt ihn um, verchristlicht ihn und predigt ihn kraft göttlicher Inspiration." First and most importantly, it is not clear whether they indicated a religious judgment by Cumont, or if they contain a tongue-in-cheek use of a general expression. Next, whether they represent any (religious or tongue-in-cheek) statement by Cumont or rather a view Cumont ascribes to Paul. If we take it the words were written from the perspective of Paul himself, he then thought he was preaching and/or Christianizing "kraft göttlicher Inspiration." But their position at the end of the sentence also makes it hard to tell whether they refer only to Paul's preaching or to all of the constituents of the phrase, in-

\footnotetext{
${ }^{48}$ Cumont, "Die orientalischen Religionen" (cf. note 41), 256.

${ }^{49}$ Loisy to Cumont, 13 July 1913, f ${ }^{\circ} 109$ : "Tous mes remerciements et mes félicitations pour le beau fascicule que vous m'avez envoyé. Tout cela est fort sage et d'une clarté qui doit manquer à beaucoup de vos collaborateurs. Cependant il y a, p. 256, un kraft göttlicher Inspiration qui m'inquiète un peu. J'ai peur que vous ne l'ayez pas entendu au même sens que l'éditeur et beaucoup de vos graves lecteurs allemands et protestants."
} 
cluding the transforming and the Christianizing. And thirdly, if only referring to Paul's preaching, the words can still mean two different things: either the "divine inspiration" concerns the intensity and the commitment with which Paul preached, or they refer to the Truth of the content of Paul's preaching. Given his prominent role in Catholic Modernism, which aimed at the emancipation of the discipline of history from theology, Loisy was sensitive to the use of theological language in a historical discourse and felt he needed to warn Cumont though teasingly, so he probably chose interpretation one - for possible misinterpretations by his religious readers.

Cumont's answer was not long in coming. In his letter of July 17, 1913 he exclaimed: "The sentence you point out is really the delicate point of my exposition! It nearly caused a quarrel with my translator, Pastor und Kreisschulinspektor at Goslar." ${ }^{50}$ Cumont explained that the pastor who had translated the original French text at first didn't want to admit any influence of the mysteries on Paul. "Kraft göttlicher Inspiration" were the words of his translator, Cumont wrote: "I was happy that he clung to a kraft which does not entirely render my French." ${ }^{51}$ The following sentence makes clear that Cumont personally understood the expression as referring only to the preaching of Paul and essentially bearing on Paul's own perspective:

"Whether the divine inspiration which made the mystic of Tarsus talk was real or imaginary, that is a question of faith or of metaphysics, which only has a secondary importance for historians who occupy themselves with terrestrial matters. Let the pious believe, as long as they listen." ${ }_{52}$

With this powerful wording, Cumont took side with the historians, whom he opposed to the "pious," who could believe what they wanted, as long as they were open-minded enough to listen to the arguments of historians like Cumont himself.

Cumont's passive correspondence points out that the pastor he was talking about was Georg Gehrich, who had also translated The Mysteries of Mithras and The Oriental Religions. Cumont's archive contains 38 letters of Gehrich, 2 of which deal with the translation of the Kultur der Gegenwart article. Cumont's answers have probably been lost. The most interesting letter dates from November 6, 1912 and discusses the paragraph on Paul. As Cumont mentioned, Gehrich indeed raised objections against the influence of the mysteries on Paul. He insisted on Paul's Jewish background and argued that the pagan mysteries were only of secondary importance. Interestingly, Gehrich mentioned Cumont's original French wording, while opposing his own views:

\footnotetext{
${ }^{50}$ Cumont to Loisy, 14 July 1913, fo 168: "La phrase que vous relevez est vraiment le point délicat de mon exposé ! Elle a failli me brouiller avec mon traducteur, Pastor und Kreisschulinspektor à Goslar."

${ }^{51}$ Ibid.: "J'ai été heureux qu'il se raccrochât à une kraft qui ne rend pas absolument mon français"

${ }^{52}$ Ibid.: "L'inspiration divine, qui fait parler le mystique de Tarse était-elle réelle ou illusoire, c'est là une question de foi ou de métaphysique qui pour les historiens, qui préoccupent les faits terrestres n'a qu'une importance secondaire. Que les dévots croient pourvu qu'ils écoutent."
} 
"Nur den Ausführungen über den Apostel Paulus konnte ich nicht immer beipflichten. Ich würde für meine Person eher sagen: 'Paulus hat das Evangelium in die Formen der Mysterien gegossen' als: 'il s'empare de leur contenu, le transforme, le christianise et l'impose en vertu d'une inspiration divine."”53

This citation shows that, just as many other Christian scholars, the translator indeed had difficulties with Cumont's view that Paul had Christianized the actual content of the mystery cults. But secondly and more importantly, it indicates that "kraft göttlicher Inspiration" was a faithful translation of Cumont's original words, and not a free addition of Gehrich himself. So, surprisingly, Cumont had given the truth a little twist in his letter to Loisy and refused to take responsibility for what he had written himself. But why? Most probably, Cumont had born into mind the religious background of his German readership, when writing his article. Accordingly, he could have tried to address the ,pious“ in a language familiar to them, while still trying to make them listen to what he and Loisy basically agreed upon: that Paul was deeply influenced by the pagan mysteries. We can in any way rule out the possibility that the words reveal a religious judgment of Cumont himself. Cumont felt strongly about his scientific reputation as a historian and his firm words to Loisy indicate that he didn't regard „divine inspiration” as a historical fact. In his letter to Loisy, he possibly tried to pin the use of language to Gehrich, because he presumed that Loisy would never have approved his compromise.

To conclude this part, we need to point out that Cumont chose not to mention Loisy's "The Christian Mystery" in the accompanying bibliography of the article. This omission most probably resulted from the pronounced nationalistic character of the encyclopedia, which was primarily aimed at exalting German scholarship. ${ }^{54}$

Cumont's and Loisy's evaluation of Paul's role in the formation of the Christian mystery

It is now time to pursue the first point of difference which Cumont's article seemed to reveal. Cumont's paragraph on Paul, and especially the sentence "Der gewaltige Mystiker (...) eignet sich vielmehr ihren Gehalt an, wandelt ihn um, verchristlicht ihn und predigt ihn kraft göttlicher Inspiration" seemed to indicate that Cumont considered the creation of the Christian mystery mainly as Paul's work and as the result of a more or less conscious process. We've seen that Loisy, on the other hand, tried to restrict Paul's individual role and that

\footnotetext{
${ }^{53}$ Gehrich to Cumont, 6 November 1912, Academia Belgica, cote 5477: "Only with the explanations about the Apostle Paul I cannot always agree. Personally, I would rather say 'Paul has cast the Gospel in the forms of the Mysteries', than: 'he seizes their content, transforms it, Christianizes it and imposes it by virtue of divine inspiration'."

${ }^{54}$ For the paragraph on Paul, Cumont referred to Wilhelm Bousset's "Die Religionsgeschichte und das Neue Testament”, Theologische Rundschau XV (1912): 251-278; to Aldof Deissmann's Paulus (Tübingen 1911); and to Hans Böhlig's Die Geisteskultur von Tarsos im Augusteischen Zeitalter mit Berücksichtigung der Paulinischen Schriften (Göttingen 1913). The mentioned letter of Gehrich shows us that it was Gehrich who suggested to Cumont to cite the work of Deissmann and Böhlig, in addition to Bousset.
} 
he claimed that he could not have transformed Jesus' gospel into a mystery of salvation "in full consciousness of his aim, and with deliberate intention."

In 1914, after having published the articles on the pagan mysteries, Loisy successively published the four French articles which constituted his in-depth study of the Christian mystery. ${ }^{55} \mathrm{He}$ sent his articles to Cumont and eagerly asked for his opinion. In most of his letters, Cumont restricted himself to congratulating Loisy. He only made an exception for "L'Évangile de Paul," which is by the way the only one of the four articles which does not deal with Christian rites. In his letter of May 11, 1914, Cumont wrote about this article: "Your penetrating analysis made me understand the Pauline doctrines for the very first time." ${ }^{56}$ Yet, in spite of his positive evaluation, he also raised a critical objection. Cumont formulated this objection as one that could be made by other scholars, but this was probably only a way to somewhat disguise his own opinion:

"But they - and by they I mean those who reason about these questions without prejudice - they will, I think, raise an objection against you: that is that you consider the doctrine of Paul as a unity given at one moment in time. Isn't it possible to follow the development letter by letter and to demonstrate how this at the same time confident and subtle spirit drew subsequent conclusions from presupposed premises?"57

From this letter, it becomes clear that Cumont felt he had to point out the evolution of Pauline theology and needed to underline Paul's creative genius. On May 24, 1914, Loisy wrote an answer to Cumont, stating that he didn't really understand what the problem was. He replied to Cumont with a very acceptable counter-argument: how was one to demonstrate evolution in Pauline thought when one only disposed of four uncontested letters? Unfortunately, Cumont's answer to this letter is lost. Yet, Cumont had an excellent command of ancient pagan and Christian literary sources, so it is rather difficult to believe that he hadn't thought of the poor source material for the reconstruction of Pauline thought himself. More probably, he wanted to point out to Loisy that Paul's contribution to the conception of Christ as a dying and resurrecting savior god was the result of a logical and relatively conscious thought process.

Earlier, we've explained Loisy's delimitation of Paul's individual role as a result of his supra-individualistic framework. In such a discourse, the evolution of Paul's individual thought and the logic of his intellectual contribution are necessarily subordinate to the evolutionistic patterns in the history of religions. In

55 “L'Évangile de Jésus et le Christ ressuscité,” RHLR (1914), 63-87; “L'Évangile de Paul,” RHLR (1914), 138-174; ,„L'initiation chrétienne,” RHLR (1914), 193-226; “La conversion de Paul et la naissance du Christianisme, “RHLR (1914), 289-331.

${ }^{56}$ Cumont to Loisy, 11 May 1914, f $164-165$ : "Votre pénétrante analyse de la doctrine paulinienne me l'a fait pour la première fois comprendre."

${ }^{57}$ Ibid.: "Mais on vous fera-j'entends par on ceux qui raisonnent de ces questions sans préjugés - on vous fera, je crois, une objection : c'est que vous considérez la doctrine de Paul comme un tout une fois donné. Ne peut-on en suivre le développement d'épître à épître et montrer comment cet esprit à la fois confiant et subtil a tiré des conclusions successives de prémisses ainsi supposées ?" 
historiography, the attempt to reconcile the systematical patterns which historians like Loisy observe with the contribution of influential individuals is in fact a perpetual moot point. Yet, there may be two other reasons for Loisy's tendency to downsize Paul's role. For the first one, we need to turn to Loisy's answer of May 24. After having indicated the lack of sources to study Paul's evolution, Loisy added:

"Besides, I don't believe that the thought of Paul changed that much in the period covered by the authentic epistles; nor that it logically developed from a given principle (that man had the least logical mind ever; when he seems to reason, these are only ideas or words which are fighting in his head)." ${ }^{58}$

The unfavorable judgment Loisy here passed on Paul's intellectual capacities, corresponded with the negative views he regularly exposed in his published work. ${ }^{59}$ In many of Loisy's letters to Cumont, these skeptical views were closely related to Loisy's disapproval of the important role Protestantism used to attribute to Paul. Prompted by his Catholic past, Loisy frequently challenged the Protestant idealization of Paul's individual religious role ${ }^{60}$, which can e.g. also be observed in Reitzenstein's Hellenistischen Mysterienreligionen.${ }^{61}$ Within the scope of this paper, we cannot explore this particular dimension of Loisy's letters to Cumont about Paul in detail. We just need to mention that, in his letters to Loisy, Cumont never took account of these anti-Protestant comments.

A third reason why Loisy might have toned down Paul's contribution, and, more specifically, why he emphasized that Paul did not transform Jesus' gospel into a mystery "in full consciousness," is related to Loisy's Christian background. Several passages of MPMC reveal that, in Loisy's view, Christianity had indeed become a mystery, but was a mystery superior to all its pagan counterparts. ${ }^{62}$ Consequently, we need to consider the possibility that for Loisy, admitting a fully conscious borrowing, even when it was a non-mechanical one, went too far. Cumont, for his part, was also influenced by this early twentieth century Christianocentrism. He was raised Catholic by his mother, but renounced this

${ }^{58}$ Loisy to Cumont, 24 May 1914, fo 120: "Je ne crois pas d'ailleurs que la pensée de Paul se soit tant modifiée dans la période que couvrent les Epitres authentiques; ni qu'elle ne se soit développée logiquement en partant d'un principe donné (cet homme était la tête la moins logique du monde ; quand il a l'air de raisonner ce sont seulement des idées ou des mots que se battent dans son cerveau)."

${ }^{59}$ E.g. Loisy, "L'Évangile de Paul," 159.

${ }^{60}$ The anti-Protestant bias of some of Loisy's letters to Cumont about Paul has been underlined by Alan H. Jones, Independence and Exegesis, Tübingen1983, 82, n. 23 and by François Laplanche, La crise de l'origine, Paris 2006, 112, n. 4.

${ }^{61}$ Richard Reitzenstein, Die hellenistischen Mysterienreligionen nach ihren Grundgedanken und Wirkungen, Leipzig 1920 (2 $2^{\text {nd }}$ edition), 63: "Daß Paulus auf die Anschauungen der Gemeinden, an die er schreibt, Rücksicht nimmt und sich müht, auf ihre Sprache und Vorstellungen einzugehen (...), müßte selbstverständlich sein. Insofern ist ein Zusammenwirken indirekter und direkter (also zunächst hellenistisch-jüdischer und später rein hellenistscher) Einflüsse von vornherein wahrscheinlich. Nur darf man das Innerste und Persönlichste in der Religiosität des Paulus nicht auf dem Glauben seiner späteren Gemeinden herleiten." For the German concept of "Religiosität" in early $20^{\text {th }}$ century religious studies, cf. Krech, Wissenschaft und Religion (cf. note 6), 9-38.

${ }^{62}$ Alfred Loisy, Les Mystères Païens et le Mystère Chrétien, Frankfurt/Main 1983, 324, 330, 332, 343,349 (reprint of the $2^{\text {nd }}$ edition of 1930). 
faith as an adolescent. ${ }^{63}$ Cumont's work reflects the conviction that Christianity was the most perfect interpretation of religion, the logical end result of religious evolution and the best religion for man in the $20^{\text {th }}$ century. ${ }^{64}$ But as for the Pauline dependence on pagan religion, Cumont had less of a problem with a rather intentional and conscious use of pagan conceptions by Paul, and could have been less sensitive to the depreciation of Christianity's originality which this intentionality implied.

Ritual and faith. Paul's conception of salvation and its relation to the pagan mystery cults

The second dissimilarity consists in the fact that, apparently, Cumont did not attribute a role to Paul within the process of development of the Christian rites of initiation. Loisy, for his part, had elaborated this crucial component of his mystery thesis in MPMC, where he pursued the ideas set forth in "The Christian Mystery“: Paul had rationalized the practices of Jesus and his disciples by interpreting them as a means to enter into communion with Christ. Judging from the preserved letters, Cumont did not react to Loisy's theory in 1914. For a captivating discussion of the importance of ritual in Pauline thought, we need to turn to the letters of December 1915. They will help us clarify that the scholars' positions were indeed divergent. Early 1916, Loisy published his commentary on the epistle to the Galatians. He dedicated the larger part of his introduction to Paul's much debated rejection of the Law. In his letter of December 18, 1915, Cumont thanked Loisy for having sent his L'épître aux Galates and brought up the relation of Paul's conception of salvation to that of the pagan mysteries. In both a prudish and humoristic way, he observed:

"I've been saying to myself that the question which distressed the Christian communities must also have been discussed in the pagan Mysteries. They must have asked themselves if faith sufficed for salvation or if the meticulous observance of the ritual practices was indispensable. In exchange of the ablation and oblation of you know what, a gallus must have considered himself more sure of seeing the gates of heaven open for him than a Jew who sacrificed his prepuce." ${ }^{65}$

${ }^{63}$ At a more advanced age, Cumont appeared to have become more spiritual. Cf. Corinne Bonnet, "Lux Perpetua: un testament spirituel," in Corinne Bonnet/Carlo Ossola/John Scheid, eds., Rome et ses religions: culte, morale, spiritualité. En relisant Lux Perpetua de Franz Cumont, Mythos. Rivista di Storia delle Religioni Suppl. I (2010), 125-141.

${ }^{64}$ This discourse is constantly used in his oeuvre. It is for instance clear in Les Religions Orientales (cited in note 8), 211, 251, but also in "Hypsistos," Revue de l'Instruction publique en Belgique XL (1897), 7-8. Both Corinne Bonnet and Danny Praet have studied Cumont's evolutionistic ideas: BonnetVan Haeperen, "Introduction historiographique," in Les Religions Orientales (cf. note 8), xxxiii-xxxvi; Danny Praet, "Le néopythagorisme, les Baals syriens et les divinités planétaires. Les théories de Franz Cumont et le cas de la Vie d'Apollonius de Tyane," in Corinne Bonnet/Vinciane Pirenne-Delforge/ Danny Praet, eds., Les religions orientales dans le monde grec et romain: cent ans après Franz Cumont (1906-2006), Rome/Bruxelles 2009, 370-374 and Danny Praet, "Wird rein durch Feuer, Wasser, Luft und Erden. Teleologie, universalisme en de symboliek van de elementen in de godsdienst-filosofie van Franz Cumont," Tom Claes, ed., Festschrift R. Commers (Gent 2012).

${ }^{65}$ Cumont to Loisy, 18 December 1915, fo 186 : "Je me suis dit que dans les Mystères païens aussi la question qui troublait les communautés chrétiennes a dû être agitée. On a dû se demander si la foi 
Cumont's comparison reveals two important aspects of his thought. First of all, it says a lot about his understanding of the pagan mystery cults. Cumont believed that worshippers of the pagan mystery gods had considered the possibility that their faith sufficed to obtain immortality. Still, he also acknowledged the importance of ritual practice in these cults. To fully understand his views, we need to mention that the general perspective from which Cumont used to study religion was rather different from that of Loisy. Earlier research done by Corinne Bonnet showed that Cumont's primary interest was in faith and spirituality (croire), rather than in practice (faire) ${ }^{66}$ In his work, as well as in the abovecited letter, Cumont did not neglect the rites of the pagan cults ${ }^{67}$, but, as Danny Praet has shown ${ }^{68}$, he did consider them inferior to the philosophical interpretations which the intellectuals of the upper levels of the "religions orientales" had given to these rites. Cumont attached great importance to the speculative and philosophical function of these religions. In his evolutionistic scheme they represented a higher stage of development than the ritualism of traditional Roman religion, and in this respect (as in many others) they paved the way for Christianity. Modern research in Roman religion, and in the pagan mystery cults more specifically, has proven Cumont wrong in centering such an interiorized sense of faith and in giving priority to the interpretation of rites, rather than to the rites themselves. Scholars as John Scheid or the triad Beard-North-Price not only toned down the alleged weight of the pagan mystery cults in Roman religion and their preparatory role for the spread of Christianity, but also demonstrated their inherently ritualistic character. ${ }^{69}$ Cumont (and many of his contemporaries ) - it is now generally agreed upon - gave these cults an interpretation which resulted from a Christianocentric perspective. ${ }^{70}$

The second point has to do with Cumont's understanding of Pauline thought. In Galatians Paul had indeed furiously rejected the Law, which his Judeo-

suffisait au salut ou si l'observance minutieuse des pratiques rituelles était indispensable. Un galle, moyennant l'ablation et l'oblation de ce que vous savez devait se croire encore plus certain qu'un juif ayant sacrifié son prépuce, de se voir ouvrir les portes du ciel."

${ }^{66}$ Corinne Bonnet, "'L'histoire séculière et profane des religions' (F. Cumont): observations sur l'articulation entre rite et croyance dans l'historiographie des religions de la fin du XIX ${ }^{\mathrm{e}}$ siècle et de la première moitié du XX ${ }^{\mathrm{e}}$ siècle," in John Scheid, ed., Rites et croyances dans les religions du monde romain, Genève 2007, 1-37.

${ }^{67}$ Cf. his studies on the taurobolium: "Le taurobole et le culte d'Anahita," Revue Archéologique XII (1888): 132-136 and "Le taurobole et le culte de Bellone," RHLR (1901): 97-110. Both articles and the correspondence Loisy and Cumont conducted on the subject have been studied by Danny Praet (Loisy conference in Lausanne, 2011), "Symbolisme, évolution rituelle et morale dans l'histoire des religions: le cas du Taurobolium dans les publications et la correspondance de Franz Cumont et d'Alfred Loisy," to be published in the conference proceedings : Alfred Loisy dans l'histoire de l'exégèse biblique et des sciences des religions, in La Revue de l'Histoire des Religions.

${ }^{68}$ Danny Praet, "Les liens entre philosophie et religion dans quelques Scripta Minora de Franz Cumont," in Corinne Bonnet, Carlo Ossola, John Scheid, eds., Rome et ses religions: culte, morale, spiritualité. En relisant Lux Perpetua de Franz Cumont, Mythos. Rivista di Storia delle Religioni Suppl. I (2010), 99-105.

${ }^{69}$ Mary Beard, John North, Simon Price, Religions of Rome. Volume I: A History, Cambridge 1998, 42-43; John Scheid, La religion des Romains, Paris 2007, 33, 147.

${ }^{70}$ James B. Rives, "Graeco-Roman Religion in the Roman Empire: Old Assumptions and New Approaches," Currents in Biblical Research 8 (2010): 249-252. 
Christian colleagues wanted to force upon the gentile, Galatian converts. Led by Paul's rejection of Judaic practice, which is also clear in the epistle to the Romans, Cumont thought that Early Christian communities had also considered the possibility that faith sufficed. By drawing attention to Paul's predominant sola-fide-idea, Cumont rightly cast doubt on Loisy's view that Pauline theology was inextricably connected to the Christian rites of salvation, baptism and the Lord's Supper. For Loisy, so we've seen, theology was a secondary product of religion, which in itself consisted in rites and (not or) the faith attached to them. In his answer to Cumont, Loisy would certainly not fail to notice his friend's different opinion. Finally, we should add that, at this point of the correspondence, it is still unclear whether Cumont thought that Paul had actually borrowed his concept of salvation from the pagan mystery cults.

One week later, on the day after Christmas, the discussion about Christianity and the pagan mystery cults continued. On December 26, 1915, Loisy wrote that he did not agree with Cumont:

"I don't believe that the question of faith and works posed itself in the mysteries as it posed itself to saint Paul. He rejected the practice of the Law because they constituted a whole which was completely alien to his mystery of salvation. He did not so much regret that one believed in rite in itself, because he attributed a mystic value to baptism and to the Eucharist. The absolute distinction he draws between faith and the Law, which is works and rites, mainly had a polemical value (...). Faith and works or rites are not mutually exclusive, because it's faith which makes up the merit of works and the power of rites. The mutilation of the gallus doesn't save him independently of the faith which has provoked this mutilation. And the mosaic rites are only incompatible with the Christian faith because they express another faith." ${ }^{\prime 1}$

In his letter, Loisy warned Cumont against adopting Paul's "absolute distinction" between faith and ritual practice without question and for applying it to the pagan mysteries. He explained that Paul had drawn this distinction so radically because of polemical reasons. In reality, Loisy argued, Paul did not attribute such an exclusive role to faith in his conception of salvation, as he tried to make his judaizing opponents believe. We've indeed seen that, according to Loisy's theory about the Christian mystery, Paul had attributed great importance to baptism and the Eucharist, and that he had even been the one who had invented the Eucharist's institution by Jesus himself. Besides, Loisy explained to Cumont, faith and myth were connected to ritual. Paul had thus drawn an "absolute distinction," which, according to Loisy, could not be drawn. Paul's rejection of

${ }^{71}$ Loisy to Cumont, 26 December 1915, fo 159: "Il ne me semble pas que la question de la foi et des œuvres se soit posée dans les mystères comme elle se posait pour saint Paul. Celui-ci répudie les pratiques de la Loi parce qu'elles constituent un ensemble complètement étranger à son mystère de salut. Il ne regrette pas autant qu' on pouvait croire lerite comme tel, car il attribue une valeur mystique au baptême et à l'eucharistie. La distinction absolue qu'il établit entre la foi et la Loi, qui est l'œuvre et le rite, a surtout une valeur polémique (...). La foi et les œuvres ou les rites ne sont pas choses qui s'excluent réciproquement, attendu que c'est la foi qui fait le mérite des œuvres et la vertu des rites. La mutilation du galle ne le sauve pas indépendamment de la foi qui a provoqué cette mutilation. Et les rites mosaïques ne sont incompatibles avec la foi chrétienne que parce qu'ils expriment une autre foi." 
the Law did not so much result from his belief that only faith could lead to redemption, as from the fact that the Law was anchored in Judaic tradition and simply didn't correspond anymore to his Christian theory of salvation.

To understand why Loisy so strongly hung on to Paul's role within the formation of the Christian ritual, we need to draw attention to the confessional background of this subject. Within the debates over Christianity's relation to the pagan mystery cults, the question of Paul's contribution to the Christian sacraments was a particularly charged point of discussion. In the wake of Luther, who had chiefly based the sola-fide-sola-scriptura-principle on Galatians and Paul's rejection of the Law ${ }^{72}$, many of Loisy's Protestant colleagues in history of Christianity denied that Paul had taken a significant part in the creation of Christian rites. ${ }^{73}$ Loisy's letter to Cumont makes it perfectly clear that even an excommunicated priest like Loisy felt that this Protestant, markedly non-ritualistic interpretation of Paul needed to be challenged, and consequently that Loisy's reasons for emphasizing the ritualistic dimension of religion were not merely scientific:

"The absolute distinction he [Paul] draws between faith and the Law, which is works and rites, mainly had a polemical value. It were rather the Protestants who made an absolute principle of it. Paul certainly did not in any way draw the conclusions with respect to the Christian sacraments which those Sirs of the Reformation wanted to draw from it. Note that the Reformation has taken up against the Catholic Church Paul's distinction, the opposition of faith to law." 74

Unfortunately, Cumont's answer to Loisy again seems to be lost. On January 12, 1916, Loisy wrote an answer to this lost letter. Before discussing its content, we need to point out that it is highly probable that Cumont had passed over Loisy's remarks about the Protestant claims on Paul in his lost letter. This conjecture we base on the fact that, as we mentioned before, he never reacted to the anti-Protestant comments Loisy had formulated elsewhere in his letters. The "divine inspiration" episode furthermore illustrates that Cumont was probably not as sensitive to the religious undertone of the debates as he wanted Loisy to believe. Regarding Pauline thought, Cumont seemed to be lacking Loisy's confessional susceptibility.

Loisy's answer of January 12 enables us to reconstruct Cumont's opinion about his friend's objections against the comparison he had drawn earlier:

${ }^{72}$ Stephen Chester, "Paul and the Galatian believers," in Stephen Westerholm, ed., The Blackwell Companion on Paul, Oxford 2011, 63-64 and Mickey L. Mattox, "Luther," in ibid., 375-390.

${ }^{73}$ For further information about Protestant scholarship on this matter: Smith, Drudgery divine (cf. note 7), especially 13-26 and Christoph Auffarth, "Licht vom Osten': Die antike Mysterienkulte als Vorlaüfer, Gegenmodell oder katholisches Gift zum Christentum,” Archiv für Religionsgeschichte 8 (2006), 211-215.

${ }^{74}$ Loisy to Cumont, 26 December 1915, f $\mathrm{f}^{\circ} 159$ : "La distinction absolue qu'il établi entre la foi et la Loi, qui est l'œuvre et le rite, a surtout une valeur polémique. Ce sont plutôt les protestants qui l'ont érigée en principe absolu. Paul, en tout cas, n'en tirait point par rapport aux sacrements chrétiens les conséquences que ces Messieurs de la Réforme en ont voulu tirer. Notez que la Réforme a repris contre l'Eglise catholique la distinction de Paul, l'opposition de la foi à la Loi." 
"It is certain that in the mysteries one was saved through faith and through the grace of the gods, not through merits, and that on that account, the theory of Paul could and needed to be influenced by the mysteries. But the afore-mentioned Paul contends that one is saved through faith without law, and that is something a follower of Isis or Mithras would never have said. But this is because the great apostle, to escape from the Mosaic Law contests law in its entirety, and only knows welfare as a fruit of the spirit. The Church did not follow him at all. But all of the aberrant Gnostics could call upon him." 75

From Loisy's answer we can derive with relative certainty that Cumont had not let go of the analogy he saw between Paul's salvation through faith and the conception of salvation in the pagan mysteries. In accordance with his understanding of the "religions orientales," Cumont might have reemphasized that faith was the most important condition to salvation in these cults, while the merits of the worshippers - it is unclear whether we are dealing with moral merits or with merits resulting from the correct performing of ritual actions are secondary. Although we need to stress the hypothetical character of our reconstruction, it is likely that Cumont had not only drawn a parallel, but had written that Paul had actually borrowed his doctrine of salvation from the pagan mysteries. In his answer to Cumont's first letter, - this we need to keep in mind - Loisy had mainly tried to prove that Cumont was misunderstanding the Pauline distinction between faith and Law, but had not really entered into Cumont's comparison with the pagan mystery cults. Contrary to Loisy, whose expertise in Early Christianity certainly determined his afore-mentioned focus, Cumont's specialty was precisely in the pagan mystery cults, so that, logically, he could have redrawn attention to these cults in his second letter.

As for Loisy's second reaction to Cumont's analogy, it is very interesting to see that he agreed with Cumont that Pauline theory was influenced by the pagan conception of salvation on the one hand, but somehow felt that Cumont's comparison did not entirely hold good on the other hand. Loisy indeed mitigated his initial agreement with Cumont by differentiating between the Pauline salvation through faith only, and the pagan mysteries, where rites indeed always remained essential. Modern scholarship - so we've seen - has proven Loisy right in making this difference between Christian and pagan religion. However, from the perspective of his statements about Paul's ritualism, Loisy's attempt at differentiation implied a serious inconsistency, as it compelled him to tone down Paul's importance in the formation of the Christian sacraments and to emphasize that Paul regarded salvation essentially as a "fruit de l'esprit," just as the Protestant scholars he had earlier dissociated himself from, had done.

\footnotetext{
${ }^{75}$ Loisy to Cumont, 12 January 1916, fo 140: "Il est certain que dans les mystères on était sauvé par la foi et par la grâce des dieux, non par mérites, et de ce chef, la théorie de Paul a pu et dû être influencé par les mystères. Mais le susdit Paul prétend qu'on est sauvé par la foi sans loi, et c'est ce qu'on n'aurait jamais dit chez Isis ni chez Mithra. Mais c'est que le grand apôtre, pour échapper à la Loi mosaïque nie en bloc toute loi, et ne connait le bien que comme fruit de l'esprit. L'Eglise ne l'a point suivi. Mais tous les gnostiques aberrants pouvaient se réclamer de lui."
} 


\section{Conclusion}

Loisy and Cumont both attributed a major role to Paul in the development of Early Christianity and agreed upon the fundamental influence of the pagan mystery cults on his thought. Still, the question of how this role and dependence were to be interpreted, they answered differently. Whereas Loisy emphasized that Paul had not "in full consciousness" depended on the mystery cults to shape the Christian mystery, Cumont seemed to regard the Pauline mystery theory as the result of a conscious interaction with the pagan environment. As for Paul's contribution to the formation of Christian rites of initiation, Loisy made the Pauline pagan-mystic reinterpretation the central point of his theory. As far as we know, Cumont, on the other hand, did not pay much attention to ritual in Pauline thought, but focused on the priority Paul had given to faith as a means to be saved and herein recognized a clear influence of the pagan mystery cults. To understand these divergent views, two explanatory courses have been pursued. Both differing methodological approaches and a dissimilar awareness of the confessional pregnancy of the discussion about Paul's role can account for their differences of opinion. The Kultur der Gegenwart episode in particular illustrated just how delicate the subject of Paul's relation to the pagan cults really was at that time. The present paper tried to give a first reconstruction and presentation of Loisy's and Cumont's epistolary reflections on Paul, though many other passages of the correspondence still need to be studied in order to have an complete picture of their views on Paul. 